\title{
Colonization of Aspergillus japonicus on synthetic materials and application to the production of fructooligosaccharides
}

\author{
Solange I. Mussatto ${ }^{\mathrm{a}, *}$, Cristóbal N. Aguilar $^{\mathrm{b}}$, Lígia R. Rodrigues ${ }^{\mathrm{a}}$, José A. Teixeira ${ }^{\mathrm{a}}$ \\ a IBB-Institute for Biotechnology and Bioengineering, Centre of Biological Engineering, University of Minho, Campus de Gualtar, 4710-057 Braga, Portugal \\ ${ }^{\mathrm{b}}$ Food Research Department, School of Chemistry, Universidad Autónoma de Coahuila, Saltillo, MX-25000 Coahuila, Mexico
}

\section{A R T I C L E I N F O}

\section{Article history:}

Received 12 December 2008

Received in revised form 28 January 2009

Accepted 30 January 2009

Available online 4 February 2009

\section{Keywords:}

$\beta$-Fructofuranosidase

Aspergillus

Fermentation

Fructooligosaccharides

Immobilization

\begin{abstract}
A B S T R A C T
The ability of Aspergillus japonicus ATCC 20236 to colonize different synthetic materials (polyurethane foam, stainless steel sponge, vegetal fiber, pumice stones, zeolites, and foam glass) and to produce fructooligosaccharides (FOS) from sucrose $(165 \mathrm{~g} / \mathrm{L})$ is described. Cells were immobilized in situ by absorption, through direct contact with the carrier particles at the beginning of fermentation. Vegetal fiber was the best immobilization carrier as A. japonicus grew well on it $(1.25 \mathrm{~g} / \mathrm{g}$ carrier), producing $116.3 \mathrm{~g} / \mathrm{L}$ FOS (56.3 g/L 1-kestose, $46.9 \mathrm{~g} / \mathrm{L}$ 1-nystose, and $13.1 \mathrm{~g} / \mathrm{L} 1$ - $\beta$-fructofuranosyl nystose) with $69 \%$ yield (78\% based only in the consumed sucrose amount), giving also elevated activity of the $\beta$-fructofuranosidase enzyme $(42.9 \mathrm{U} / \mathrm{mL})$. In addition, no loss of material integrity, over a 2 day-period, was found. The fungus also immobilized well on stainless steel sponge ( $1.13 \mathrm{~g} / \mathrm{g}$ carrier), but in lesser extents on polyurethane foam, zeolites, and pumice stones $(0.48,0.19$, and $0.13 \mathrm{~g} / \mathrm{g}$ carrier, respectively), while on foam glass no cell adhesion was observed. When compared with the FOS and $\beta$-fructofuranosidase production by free $A$. japonicus, the results achieved using cells immobilized on vegetal fiber were closely similar. It was thus concluded that $A$. japonicus immobilized on vegetal fiber is a potential alternative for high production of FOS at industrial scale.
\end{abstract}

() 2009 Elsevier Ltd. All rights reserved.

\section{Introduction}

Interest in the use of oligosaccharides in food products has strongly increased in recent years since the consumer is becoming more and more health conscious. Among these compounds, fructooligosaccharides (FOS), particularly, are of great interest and have been widely used in food and pharmaceutical fields as functional sweeteners, due to their favourable functional characteristics such as low caloric value, non-cariogenicity, effects in decreasing the levels of phospholipids, triglycerides, and cholesterol, help in gut absorption of calcium and magnesium, usefulness in diabetic products and prebiotics to stimulate bifidobacterial growth in the human colon. ${ }^{1-3}$

FOS are fructose oligomers mainly composed of 1-kestose $\left(\mathrm{GF}_{2}\right)$, 1 -nystose $\left(\mathrm{GF}_{3}\right)$, and 1- $\beta$-fructofuranosyl nystose $\left(\mathrm{GF}_{4}\right)$, in which $1-$ 3 fructosyl units $(F)$ are bound at the $\beta-(2 \rightarrow 1)$ position of sucrose molecule (GF). Although FOS can be found in several natural

Abbreviations: WAI, water absorption index; CHP, critical humidity point; PDA, potato dextrose agar; FFase, $\beta$-fructofuranosidase; FOS, fructooligosaccharides; GF, sucrose; $\mathrm{GF}_{2}$, 1-kestose; $\mathrm{GF}_{3}, 1$-nystose; $\mathrm{GF}_{4}, 1$ - $\beta$-fructofuranosyl nystose; $U_{\mathrm{t}}$, transfructosylating activity; $U_{\mathrm{h}}$, hydrolyzing activity; HPLC, high-performance liquid chromatography; $Y_{\mathrm{P} / \mathrm{S}}$, FOS yield factor; $Q_{\mathrm{P}}$, FOS productivity.

* Corresponding author. Tel.: +351 253 604400x605413; fax: +351 253678986.

E-mail addresses: solange@deb.uminho.pt, solangemussatto@hotmail.com (S.I. Mussatto). sources such as asparagus, sugar beet, garlic, chicory, onion, Jerusalem artichoke, wheat, honey, banana, barley, tomato, and rye, ${ }^{2-4}$ their concentration in these sources is low and mass production is limited by seasonal conditions. ${ }^{5}$ On an industrial scale, FOS is mostly produced from the disaccharide sucrose by microbial enzymes having transfructosylating activity ( $\beta$-fructofuranosidases, EC.3.2.1.26, also designed as fructosyltransferases EC.2.4.1.9). Most of these enzymes have been found in fungi such as Aspergillus, Aureobasidum, and Penicillium, ${ }^{6-8}$ but few of them have potential for industrial application due to their low transfructosylating activities. $^{3}$ In the past few years, several Aspergillus japonicus strains have been reported as potentially adequate for industrial production of FOS. ${ }^{7}$

The yields of FOS production by transfructosylation are normally low (55-60\%) since the enzymes involved in the reaction exhibit, besides their transfructosylating activity, a hydrolytic activity resulting in glucose and fructose as by-products. ${ }^{3,9}$ In addition, glucose acts as inhibitor of the enzymes, affecting the reaction efficiency. ${ }^{10}$ As a consequence, there is a great interest in the development of a suitable and economically viable biotechnological process for industrial production of FOS, which would allow to obtain higher yields and a final product with a lower glucose content.

Conventionally, FOS production is a two-stage process, in which the first one is the microbial production of the enzyme by fermentation, and the second one is the enzyme reaction with sucrose 
(substrate) to produce FOS under controlled conditions. ${ }^{5}$ There are few reports about the production of FOS in a single step, that is, based on the enzyme production and enzymatic reaction in a unique fermentative process. The use of whole cells as biocatalyst, with or without immobilization, avoids the purification of FOSproducing enzymes from the cell extract, enabling FOS production in only one less expensive step. ${ }^{7,11,12}$

Immobilization of microorganisms using various methods has often been reported in fermentative processes; the entrapment in gels and the use of a matrix support being the most commonly employed techniques for mycelia immobilization. ${ }^{13}$ Several advantages have been reported for the use of immobilized cells, including (i) increased cell stability that may often result in increased cell productivity; ${ }^{14}$ (ii) increase in process efficiency due to high cell concentration in the fermentation medium; ${ }^{11}$ (iii) easier separation of the cells from the fermentation broth that allows repeated batch operations and facilitates isolation and purification of the products, ${ }^{15-17}$ (iv) higher level of activity of immobilized cultures, which appear more resistant to environmental perturbations such as $\mathrm{pH}$, or exposure to toxic chemical concentrations, as compared to cultures in suspension. ${ }^{18}$ Nevertheless, it is well known that good performance of systems based on immobilized cells mainly depends on the right selection of the immobilization carrier. In the present report, several synthetic materials were used as carriers for immobilization of A. japonicus for FOS production from sucrose. The capacity of cells to adhere to the carrier, as well as the production of FOS and $\beta$-fructofuranosidase activity, was evaluated.

\section{Experimental}

\subsection{Carrier's preparation}

Six porous carriers were tested: polyurethane foam, stainless steel sponge, vegetal fiber (Scotch Brite, 3M Spain, SA), pumice stones (Elite, purchased at a local department store), zeolite molecular sieves type 4A (BDH Chemicals Ltd., Poole, England), and foam glass (Poraver ${ }^{\mathrm{TM}}$, Dennert, Poraver GmbH, Germany). Their water absorption index (WAI) was determined using the method of Anderson et al. ${ }^{19}$ Briefly, the sample $(2.5 \mathrm{~g})$ was suspended in $30 \mathrm{~mL}$ of distilled water in a tared $60 \mathrm{~mL}$ centrifuge tube. The slurry was stirred with a glass rod for $1 \mathrm{~min}$ at room temperature $\left(25^{\circ} \mathrm{C}\right)$ and centrifuged at $3000 \mathrm{~g}$ and $25^{\circ} \mathrm{C}$ for $10 \mathrm{~min}$. The supernatant was discarded, and the WAI was calculated from the weight of the remaining gel and expressed as g gel/g dry weight. The critical humidity point (CHP) was estimated by adding $1 \mathrm{~g}$ of sample to a thermobalance at $120^{\circ} \mathrm{C}$ for $60 \mathrm{~min} .^{20}$

Polyurethane foam and vegetal fiber were provided as $0.3 \mathrm{~cm}^{3}$ samples. Stainless steel sponge was used as cuttings of irregular size. Pumice stones were granules of 8-24 mesh (2.36$0.71 \mathrm{~mm}$-sieve opening), and zeolites were approximately $0.1 \mathrm{~cm}$ in diameter and $0.4 \mathrm{~cm}$ length. To be used as immobilization carriers, all these materials were pretreated by boiling for $10 \mathrm{~min}$, washing three times with distilled water, and then drying overnight at $60^{\circ} \mathrm{C}$.

Foam glasses were particles of $2.36-3.35 \mathrm{~mm}$ diameter. The particles were dried at $105{ }^{\circ} \mathrm{C}$ for $3 \mathrm{~h}$, and then treated with a $5 \%$ $\mathrm{w} / \mathrm{v} \mathrm{HNO}_{3}$ soln at $65{ }^{\circ} \mathrm{C}$ for $45 \mathrm{~min}$. Subsequently, they were washed with distilled water until neutral and dried at $90{ }^{\circ} \mathrm{C}$ to constant weight. Prior to use, all the carrier materials were autoclaved at $121^{\circ} \mathrm{C}$ for $20 \mathrm{~min}$.

\subsection{Microorganism maintenance}

The strain A. japonicus ATCC 20236 (from Micoteca da Universidade do Minho (MUM)) was used in the experiments. The strain was maintained on potato dextrose agar (PDA-Difco) plates at $4{ }^{\circ} \mathrm{C}$, and the spores were maintained in glycerol suspension in an ultra-freezer at $-80^{\circ} \mathrm{C}$. For the production of spores, the strain was grown on PDA medium, at $25-30^{\circ} \mathrm{C}$ for $7-8$ days.

\subsection{Fermentation conditions}

The fermentation experiments were carried out in $500 \mathrm{~mL}$ Erlenmeyer flasks containing $1 \mathrm{~g}$ of the immobilization material and $100 \mathrm{~mL}$ of culture medium with the following composition (\% w/v): sucrose 16.5 , yeast extract $2.75, \mathrm{NaNO}_{3} 0.2, \mathrm{~K}_{2} \mathrm{HPO}_{4} 0.5$ $\mathrm{MgSO}_{4} \cdot 7 \mathrm{H}_{2} \mathrm{O} 0.05$, and $\mathrm{KCl} 0.05$. Steam sterilization of the medium was carried out at $121^{\circ} \mathrm{C}$ for $20 \mathrm{~min}$. Flasks were inoculated with $1.0 \mathrm{~mL}$ of a spore suspension containing around $1.8 \times 10^{7}$ spores/ $\mathrm{mL}$, which was prepared by scraping down the spores from the PDA plates with a sterilized solution of $0.1 \% \mathrm{w} / \mathrm{v}$ Tween 80 , and by counting in a Neubauer chamber. The inoculated flasks were incubated in a rotary shaker at $28^{\circ} \mathrm{C}$ and $160 \mathrm{rpm}$ for $48 \mathrm{~h}$. Cells were immobilized in situ in the flasks by natural adsorption to the immobilizing material at the beginning of the fermentation. In a second step, assays under the same fermentation conditions described above, but using 20.0\% (w/v) sucrose, were performed with vegetal fiber as immobilization material, and also without addition of carrier particles (free cells assay).

Samples for analysis were collected at regular intervals and filtered using $0.2 \mu \mathrm{m}$ filters to separate the cell pellets from the culture fluid. In the filtered broth, FOS (1-kestose, 1-nystose, and 1- $\beta$ fructofuranosyl nystose), residual other sugars (sucrose, fructose, and glucose), $\mathrm{pH}$ and extracellular enzyme activity were measured. The concentrations of free and immobilized cells were determined at the fermentation end.

\subsection{Analytical methods}

\subsubsection{Cell mass concentration}

The free cell mass concentration was determined by dry weight per vol $(\mathrm{g} / \mathrm{L})$. At the end of the fermentation, the cells were collected by suction filtration of the fermentation broth through preweighed $0.45 \mu \mathrm{m}$ membranes, washed with distilled water, and dried at $105^{\circ} \mathrm{C}$ to constant weight.

The amount of cells attached to the carriers was determined after washing the support material with distilled water for three times, and drying at $105^{\circ} \mathrm{C}$ to constant weight. The biomass dry weight was determined from the difference between the mycelium plus carrier and the carrier itself.

\subsubsection{Enzymatic activity}

Samples of the fermentation media were filtered through $0.2 \mu \mathrm{m}$ membranes to remove the cell mass, and the filtrate was utilized as extracellular enzyme source.

The $\beta$-fructofuranosidase (FFase) activity was determined by measuring the amount of glucose produced from sucrose. ${ }^{21}$ The reaction mixture contained $100 \mathrm{~mL}$ of the crude FFase extract, $300 \mathrm{mmol}$ of sucrose, and $50 \mathrm{mmol}$ of sodium acetate buffer $(\mathrm{pH}$ 5.0 ) in a total volume of $1 \mathrm{~mL}$. After incubation for $20 \mathrm{~min}$ at $30^{\circ} \mathrm{C}$, the reaction was stopped by heating for $5 \mathrm{~min}$ at $100^{\circ} \mathrm{C}$. After cooling, the amount of glucose released into the supernatant was measured by high-performance liquid chromatography (HPLC, see below). One unit (U) of the FFase activity was defined as the amount of enzyme required to release $1 \mu \mathrm{mol}$ of glucose per min from sucrose under the above conditions.

\subsubsection{Transfructosylating and hydrolyzing activities}

The reaction was carried out for $180 \mathrm{~min}$ using $0.5 \mathrm{U} / \mathrm{mL}$ of FFase in the reaction mixture described above. ${ }^{21}$ Transfructosylating activity $\left(U_{\mathrm{t}}\right)$ and hydrolyzing activity $\left(U_{\mathrm{h}}\right)$ were determined by 
measuring the concentrations of 1-kestose and fructose by HPLC, respectively. One unit of transfructosylating activity was defined as the amount of enzyme required to transfer $1 \mu \mathrm{mol}$ of fructose per min. One unit of hydrolyzing activity was defined as the amount of enzyme required to release $1 \mu \mathrm{mol}$ of free fructose per min.

\subsubsection{Sugars and FOS concentrations}

FOS (1-kestose, 1 -nystose, and 1- $\beta$-fructofuranosyl nystose) and other residual sugars (sucrose, glucose, and fructose) were directly analyzed by high-performance liquid chromatography (HPLC) on an equipment LC-10 A (Jasco, Japan) with a Prevail Carbohydrate ES column $(5 \mu \mathrm{m}, 250 \times 4.6 \mathrm{~mm}$, Alltech) at room temperature, and a refractive index detector. The response of the refractive index detector was recorded and integrated using the Star Chromatography Workstation software (Varian). A mixture of 7:3 MeCN-0.04\% ammonium hydroxide in water was used as mobile phase at a flow rate of $1.0 \mathrm{~mL} / \mathrm{min}$. Before injection, the samples were filtered through $0.2 \mu \mathrm{m}$ filters and diluted with Milli-Q water when needed. The sugars and FOS concentrations were determined from standard curves made with known concentrations of each compound. The total yield of FOS ( $Y_{\mathrm{FOS}}$ in $\mathrm{g} / \mathrm{g}$ ) was calculated as the proportion of the sum of 1-kestose $\left(Y_{\mathrm{GF} 2}\right), 1$-nystose $\left(Y_{\mathrm{GF} 3}\right)$, and 1 - $\beta$-fructofuranosyl nystose $\left(Y_{\mathrm{GF} 4}\right)$, to initial sucrose concentration. The FOS productivity $\left(Q_{P}\right)$ was calculated as the total FOS production $(\mathrm{g} / \mathrm{L})$ by fermentation time $(\mathrm{h})$.

\subsection{Statistical analysis}

All the fermentation experiments were conducted at least in duplicate and the average values are reported. The relative standard deviation was less than $5 \%$. In some cases, the results were analyzed statistically using Tukey's range test. A p-value of less than 0.05 was regarded as significantly different.

\section{Results and discussion}

\subsection{Characteristics of the immobilizing materials and concentration of the immobilized cells}

WAI and CHP are parameters of great relevance when evaluating the potential of different materials for use as cell immobilization carrier or as substrate for solid-state fermentation. WAI, an indicator of the sample ability to absorb water, depends on the availability of hydrophilic groups which bind water molecules, and on the gel forming capacity of macromolecules. ${ }^{22}$ For microorganism cultivation, it is preferable to use materials with high WAI values, because they facilitate the species growth and development. As shown in Table 1, among the materials used for immobilization of $A$. japonicus, polyurethane foam and vegetal fiber had the highest WAI values, while zeolites and stainless steel sponge gave the lowest results.

Besides an elevated WAI, the materials must have low CHP to facilitate the microorganism cultivation. The higher the CHP va-

\section{Table 1}

Water absorption index (WAI) and critical humidity point (CHP) for the different materials evaluated as cells immobilization carrier

\begin{tabular}{lcl}
\hline Immobilization carrier & WAI (g/g dry matter) & CHP (\%) \\
\hline Pumice stones & 2.6 & 65 \\
Zeolites & 1.7 & 60 \\
Stainless steel sponge & 1.8 & 80 \\
Polyurethane foam & 12.2 & 40 \\
Vegetal fiber & 6.9 & 55 \\
Foam glass & 2.1 & 60 \\
\hline
\end{tabular}

Table 2

Free and immobilized cells concentration during FOS production by Aspergillus japonicus ${ }^{\mathrm{a}}$

\begin{tabular}{llc}
\hline Immobilization carrier & Immobilized cells $(\mathrm{g} / \mathrm{g}$ carrier $)$ & Free cells $(\mathrm{g} / \mathrm{L})$ \\
\hline Pumice stones & 0.13 & 20.83 \\
Zeolites & 0.19 & 19.36 \\
Stainless steel sponge & 1.13 & 2.59 \\
Polyurethane foam & 0.48 & 6.44 \\
Vegetal fiber & 1.25 & 5.09 \\
Foam glass & 0.00 & 13.13 \\
\hline
\end{tabular}

a Values after $48 \mathrm{~h}$ of fermentation.

lue, the lower the proportion of water bound to the material, and consequently, the species development will be affected. Once again, the best results were found for polyurethane foam and vegetal fiber (Table 1). Therefore, it would be expected that both materials could act successfully as carriers for A. japonicus immobilization.

Immobilized cells concentration with the different carriers are given in Table 2 . Among the evaluated materials, only porous glass was not able to immobilize cells. In addition, this material was not suitable for use as carrier since it was not stable during the experiment. Due to the light and porous structure, the particles were broken as a consequence of the collision between each other and the vessel wall. Maybe, for this reason, porous glass (Poraver) has been normally used as immobilization carrier in packed columns, ${ }^{23,24}$ where the particles are not submitted to stirring. The stability of all the carriers during the total fermentation time ( $48 \mathrm{~h}$ ) was evaluated by performing assays with carrier particles that are added to the fermentation medium without cells. Except porous glass, all the carriers were quite stable during the experiments and did not show any tendency to dissolve.

The other five materials used for $A$. japonicus immobilization were able to adhere cells, but with different capacities. Among them, pumice stones and zeolites provided the lowest immobilized cells concentration, which could be explained by their WAI and CHP values (Table 1). A major quantity of cells adhered to polyurethane foam, but the highest cell masses adhered to stainless steel sponge and vegetal fiber (Table 2 ). In the last two cases, it could be visualized that the fungus was immobilized internally and externally to the carriers, and gradually grew as a dense layer on the surface, so that at the fermentation end the entire carrier was covered with cells. Similarly, pumice stone was also not suitable for immobilization of Rhizopus arrhizus during the lipase production. ${ }^{25}$ According to the authors, this material showed strong mechanical strength that restrained the mycelia growth; immobilization on polyurethane gave the best results.

Curiously, A. japonicus adhered well on stainless steel sponge, a material that presented the worst values of WAI and CHP (Table 1). When compared with alginate beads, polyurethane foam, and nylon sponge, stainless steel sponge was also the best carrier for immobilization of the white-rot fungus Trametes hirsuta for decolourization of textile dyes. ${ }^{26}$ The fungus grew well attached to the carrier material, and the liquid phase remained clear during the whole cultivation, whereas with the other supports, part of the cells were released into the liquid.

In the present work, all the experiments had free cells in the medium besides those immobilized. Pumice stones and zeolites, which gave the lowest immobilized cells concentrations, presented the major amounts of free cells; while stainless steel sponge and vegetal fiber, which immobilized a major proportion of cells, resulted in the lowest free cells concentrations. Contrary to expectation, the medium containing foam glass as carrier (which did not immobilize cells) did not show the major free cells concentration when compared with the other media. Probably, the small particles 
of the crumbled carrier negatively affected the microorganism development in this medium.

\subsection{Sucrose uptake and FOS production with immobilized cells}

Fermentation with the different carriers had similar kinetic behaviors of sucrose consumption and FOS production, with an initial lag phase of approximately $12 \mathrm{~h}$ where little or no substrate was consumed (Fig. 1A). As a consequence, practically no FOS pro-
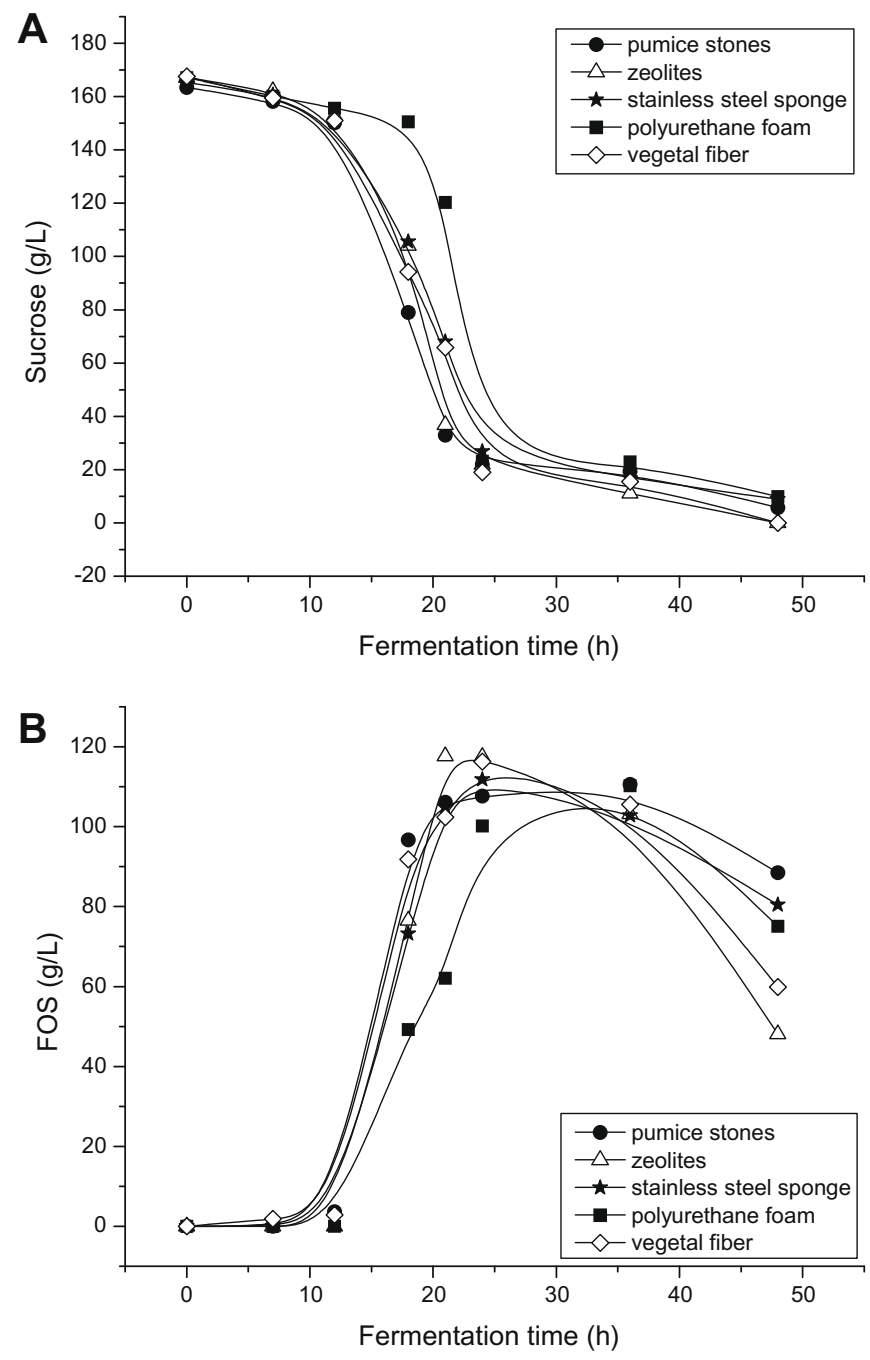

Figure 1. Sucrose uptake (A) and FOS production (B) using A. japonicus immobilized on different synthetic materials.

Table 3

Maximum production of 1-kestose, 1-nystose, and 1- $\beta$-fructofuranosyl nystose during the FOS production by Aspergillus japonicus immobilized on different synthetic materials

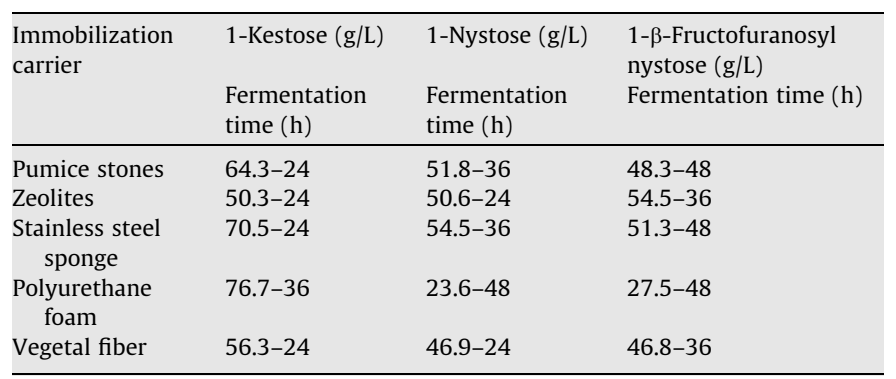

duction was observed during this period (Fig. 1B). Nevertheless, in the following $12 \mathrm{~h}$, all the processes attained the maximum FOS production, as result of the almost total depletion of sucrose. 1Kestose was the main FOS formed in all media, followed by 1-nystose and 1- $\beta$-fructofuranosyl nystose, which required larger fermentation times to be formed. On average, maximum 1-kestose concentration was observed after $24 \mathrm{~h}$ of fermentation, while the concentration of 1 - $\beta$-fructofuranosyl nystose required approximately $48 \mathrm{~h}$ to attain the highest value (Table 3 ).

A similar behavior was observed by Cruz et al. ${ }^{12}$ during FOS production by A. japonicus immobilized on calcium alginate. According to these authors, the FOS synthesis was always in the sequence $\mathrm{GF} \rightarrow \mathrm{GF}_{2} \rightarrow \mathrm{GF}_{3} \rightarrow \mathrm{GF}_{4}$, as a consequence of the increasing $\mathrm{Km}$ values for such products presented by the transfructosylase. Thus, high concentrations of the preceding oligosaccharide are always necessary for the synthesis of the homolog with one more fructose unit. This would also explain why the content of 1-kestose is higher at the beginning of the enzymatic reaction.

After an initial $24 \mathrm{~h}$ fermentation period, presumably due to sucrose exhaustion from the media, the microorganism started consuming 1-kestose, and therefore, even if formation of the other two FOS $\left(\mathrm{GF}_{3}\right.$ and $\left.\mathrm{GF}_{4}\right)$ was observed, the total FOS concentration started to decrease in all media, as can be noted in Figure 1B. Consequently, when the reaction time was extended to $48 \mathrm{~h}$, changes in the total FOS content occurred, with an increase in $\mathrm{GF}_{3}$ and $\mathrm{GF}_{4}$ contents and a corresponding loss of 1-kestose. Although the FOS mixture composition has not attracted the attention of many researchers, it is important to emphasize that increasing the length of the fructose chain decreases the sweetening power of the FOS. ${ }^{12,27}$ In addition, FOS with low DP has better therapeutic properties than those with high DP. ${ }^{28}$ Therefore, if the purpose is to obtain FOS for its sweet taste or as a sweetener product, or even for therapeutical purposes, the ideal reaction time would be around $24 \mathrm{~h}$.

Although the kinetic behaviors of sucrose consumption and FOS production were similar for all the assays, independently of the immobilization carrier used, the fermentative parameters values were different in each case, due to the differences in residual sucrose content and total FOS produced in each medium. As can be noted in Table 4, the medium containing foam glass as carrier gave the highest FOS production, in a shorter time $(21 \mathrm{~h})$ than in the other experiments, resulting in the highest productivity value $\left(Q_{P}\right)$. However, this medium contained only free cells in suspension, and it is not the aim of the present work to produce FOS from free cells.

Considering only the media containing immobilized cells, it can be observed that all of them achieved the maximum FOS concentration in $24 \mathrm{~h}$ of fermentation. Among these, the medium containing zeolites gave the best results, but cells in this medium were mostly free (only a few amount was immobilized onto the carrier) (Table 2). The medium containing vegetal fiber as carrier gave the second highest fermentative parameters values for FOS production. In fact, the achieved results were closely similar to those attained with zeolites, but vegetal fiber presented an important advantage, since it was the carrier that immobilized the major amount of cells (Table 2). This means that using vegetal fiber as carrier, it was possible to immobilize large amounts of cells and produce FOS with high yield. Stainless steel sponge was also able to successfully immobilize cells and produce FOS, yielding fermentative parameters values only $4-5 \%$ lower than those achieved with vegetal fiber. The medium containing polyurethane foam as carrier resulted in the lowest values of $Y_{\mathrm{P} / \mathrm{S}}, Q_{\mathrm{P}}$, and FOS concentration, although a significant amount of cells had been immobilized. It is possible that some mass transfer limitation occurred in this case, since polyurethane foam absorbed a larger volume of medium as compared to the other carriers. Mass transfer limitations can decrease the biological activity of the colonized carrier. ${ }^{29}$ 
Table 4

Fermentative parameters of FOS production by Aspergillus japonicus immobilized on different synthetic materials

\begin{tabular}{|c|c|c|c|c|c|}
\hline Immobilization carrier & Maximum FOS $(\mathrm{g} / \mathrm{L})$ & Fermentation time $(\mathrm{h})$ & $Y_{\mathrm{P} / \mathrm{S}}$ per total substrate $(\mathrm{g} / \mathrm{g})^{\mathrm{a}}$ & $Y_{\mathrm{P} / \mathrm{S}}$ per consumed substrate $(\mathrm{g} / \mathrm{g})^{\mathrm{b}}$ & $Q_{P}(g / L h)^{c}$ \\
\hline Pumice stones & 107.6 & 24 & 0.66 & 0.76 & 4.49 \\
\hline Zeolites & 117.5 & 24 & 0.70 & 0.81 & 4.89 \\
\hline Stainless steel sponge & 111.8 & 24 & 0.68 & 0.81 & 4.66 \\
\hline Polyurethane foam & 110.3 & 24 & 0.60 & 0.70 & 4.18 \\
\hline Vegetal fiber & 116.3 & 24 & 0.69 & 0.78 & 4.84 \\
\hline Foam glass & 130.1 & 21 & 0.62 & 0.66 & 6.20 \\
\hline
\end{tabular}

a FOS yield factor as the ratio between total FOS produced and initial sucrose concentration.

b FOS yield factor as the ratio between total FOS produced and sucrose consumed.

c FOS productivity as the ratio between FOS produced per fermentation time.

It is well known that the productivity of many fermentation processes is affected by experimental conditions such as medium composition, oxygen transfer rate, type of fermentation (submerged or not), rates of agitation and aeration, type of impeller, $\mathrm{pH}$, and temperature. ${ }^{30}$ In the present work, the used conditions were chosen based on previous works on FOS production by other Aspergillus strains. None of the used conditions was optimized for A. japonicus ATCC 20236. Even so, high fermentative parameters values were achieved. Normally, the FOS production yields are in the range of $55-60 \%(\mathrm{w} / \mathrm{w}) ;^{3,9,12}$ similar and higher yields were obtained in the present work, which could be still improved by determining the most suitable conditions for cultivation of this species.

\section{3. $\beta$-Fructofuranosidase activity}

$\beta$-Fructofuranosidase (FFase) activities by immobilized $A$. japonicus cells are shown in Figure 2 . The best value $(42.9 \mathrm{U} / \mathrm{mL})$ was found after $36 \mathrm{~h}$ cultivation, from cells immobilized on vegetal fiber. Such value was almost two times higher than that attained with cells immobilized on polyurethane foam, which provided the lowest enzyme activity. Although the production level of FFase depends to a great extent of the microorganism, basal substrate, and the microbial production process, ${ }^{31}$ the results achieved by using vegetal fiber as immobilization carrier can be favorably compared with those obtained during FOS production by other fungus strains. For example, under optimized cultivation conditions, $A$. japonicus JN-19 yielded a FFase activity of $55.42 \mathrm{U} / \mathrm{mL}$ after $96 \mathrm{~h}$ fermentation, and the FOS production yield was $55.8 \%{ }^{32}$ By using a mutant Saccharomyces cerevisiae and optimized fermentation conditions, ul-Haq et al. ${ }^{31}$ produced FFase with a specific activity of $45.65 \mathrm{U} / \mathrm{mL}$, after $48 \mathrm{~h}$ incubation time. In the present study, a

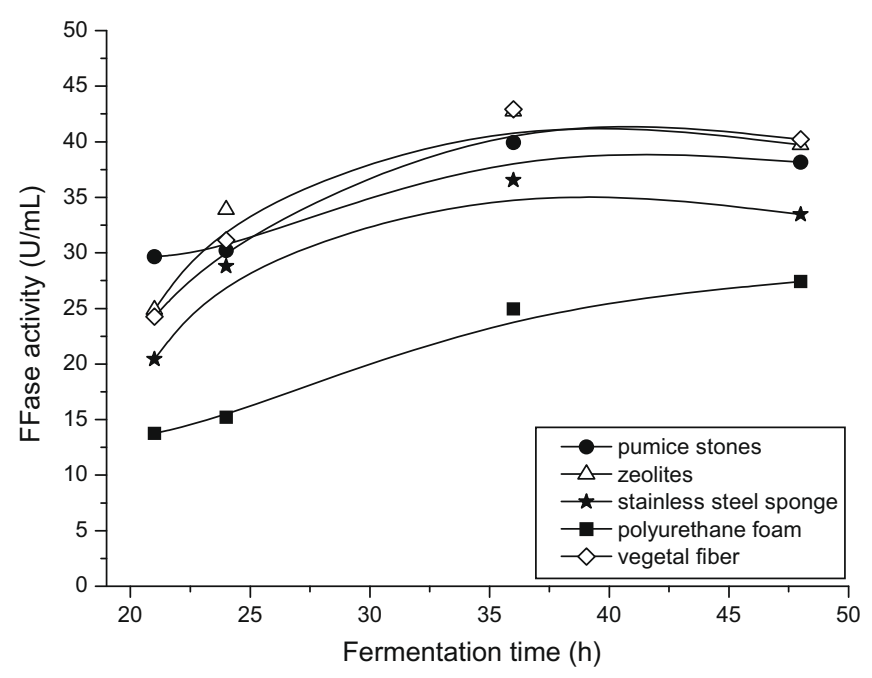

Figure 2. Kinetic curves of FFase activity by A. japonicus immobilized on different synthetic materials.
FFase activity of $42.9 \mathrm{U} / \mathrm{mL}$ was obtained only after 36 h fermentation, giving a higher productivity, and the FOS yield was $69 \%$. Such values could be still improved by establishing the best process operational conditions.

Establishing the best operational conditions is also of great importance to maximize the FFase yield. The $\mathrm{pH}$, for example, is an important variable in this process. According to Wang and $\mathrm{Zhou}^{32}$ the optimal initial $\mathrm{pH}$ values for FFase production depend on the strain, composition of the fermentation medium, and growth conditions. For $A$. japonicus $\mathrm{JN}-19$, the FFase production and growth were maximum at $\mathrm{pH} 5.5$, being restrained under acidic conditions or $\mathrm{pH}$ greater than $6.5 .{ }^{32}$ On the other hand, the $\mathrm{pH} 7.0$ was optimal for FFase production by A. niger ${ }^{33}$ and Bacillus macerans. ${ }^{34}$ In the present work, the media $\mathrm{pH}$ was set to 7.0 before inoculation and was not controlled during the experiment, being gradually decreased during the cultivation to approximately 6.3. Keeping the $\mathrm{pH}$ stable during the process could be helpful for the FFase production. ${ }^{32}$

It is also worth mentioning that although high fungal cellular growth connected with more carbon and nitrogen consumption had been correlated with decreasing enzyme production, ${ }^{35}$ such fact was not verified in our work, since the medium containing the major amount of immobilized cells gave the major FOS production and enzyme activity.

\subsection{Comparison of FOS production by free or immobilized cells}

At this stage, fermentation assays were performed in order to compare the kinetic behavior of FFase activity and FOS production, using cells immobilized on vegetal fiber or free whole cells. As can be noted in Table 5, the results obtained with the immobilized strain can be compared well to those obtained with free cells. Total FOS production, maximum concentration of each FOS individually, and the yield factors $\left(Y_{\mathrm{P} / \mathrm{S}}\right)$ were closely similar. The FOS productivity $\left(Q_{P}\right)$ was slightly higher for the free cells medium, suggesting that the maximum concentration of FOS was more quickly attained

Table 5

Fermentative parameters of FFase and FOS production by Aspergillus japonicus immobilized or not in vegetal fiber

\begin{tabular}{|c|c|c|}
\hline Fermentative parameters & Immobilized cells & Free cells \\
\hline Maximum FOS (g/L) & 134.6 & 128.7 \\
\hline Maximum 1-kestose (g/L) & 97.6 & 99.8 \\
\hline Maximum 1-nystose (g/L) & 57.6 & 65.5 \\
\hline Maximum 1- $\beta$-fructofuranosyl nystose $(\mathrm{g} / \mathrm{L}$ ) & 29.6 & 30.2 \\
\hline$Y_{\mathrm{P} / \mathrm{S}}$ per total substrate $(\mathrm{g} / \mathrm{g})^{\mathrm{a}}$ & 0.65 & 0.61 \\
\hline$Y_{\mathrm{P} / \mathrm{S}}$ per consumed substrate $(\mathrm{g} / \mathrm{g})^{\mathrm{b}}$ & 0.70 & 0.64 \\
\hline$Q_{P}(g / L h)^{C}$ & 4.49 & 5.36 \\
\hline Maximum FFase $(\mathrm{U} / \mathrm{mL})$ & 43.1 & 46.4 \\
\hline Maximum $U_{\mathrm{t}} / U_{\mathrm{h}}$ ratio & 4.8 & 3.2 \\
\hline
\end{tabular}


when using free cells. Nevertheless, according to the statistical test of Tukey $(p<0.05)$ (data not shown), the values of total FOS concentration, as well as the FFase production from free or immobilized cells, had no statistical significant difference at $95 \%$ confidence level. This means that it was possible to successfully reproduce the results of FOS and FFase production with free cells, using the cells immobilized in vegetal fiber. This is advantageous because the immobilized cells could be easily recovered from the medium and re-used several times in repeated batches, for example, eliminating the period necessary for the fungus growth and increasing the process productivity.

FFases commonly possess both hydrolytic $\left(U_{\mathrm{h}}\right)$ and transfructosylating $\left(U_{\mathrm{t}}\right)$ activities, which can be altered by modifying the reaction conditions. ${ }^{36}$ However, for an efficient production of FOS, it is preferable to have a high $U_{\mathrm{t}} / U_{\mathrm{h}}$, ratio. ${ }^{37}$ As shown in Table 5 , cells immobilized on vegetal fiber presented an $U_{\mathrm{t}} / U_{\mathrm{h}}$ ratio $50 \%$ higher as compared to free cells.

\section{Conclusions}

Porous glass was not able to immobilize cells and was found to be instable during fermentation, crumbling during agitation due to contact among particles and with the vessel walls, and being therefore unsuitable for use as immobilization carrier during FOS production. Even providing good fermentation values, pumice stones and zeolites were not able to immobilize large amount of cells, and the obtained results arose mostly from the free cells. Polyurethane foam immobilized a major amount of cells as compared to pumice stones or zeolites, but gave worst fermentation results, probably due to mass transfer problems because this material absorbed a larger volume of medium than the other evaluated carriers. Among the tested carriers, vegetal fiber was the best material for immobilization of $A$. japonicus, since the fungus remained perfectly attached to the carrier during cultivation and allowed high production of FOS and FFase activity, comparable to those found using free cells. In addition, vegetal fiber is a cheap, mechanically strong, and easy to use material, which does not require any severe or expensive pretreatment. Such material was thus selected for use in subsequent experiments aiming at maximizing FOS production by A. japonicus. From preliminary experiments, A. japonicus cells with elevated FFase activity (around $40.6 \mathrm{U} / \mathrm{mL}$ ) could be used during seven consecutive FOS production cycles, completing a total period of $192 \mathrm{~h}^{38}$

\section{Acknowledgments}

The financial support from FCT, the Portuguese Foundation for Science and Technology (research Project SFRH/BPD/38212/2007) is gratefully acknowledged.

\section{References}

1. Mussatto, S. I.; Mancilha, I. M. Carbohydr. Polym. 2007, 68, 587-597.

2. Sangeetha, P. T.; Ramesh, M. N.; Prapulla, S. G. Trends Food Sci. Technol. 2005, 16, 442-457.

3. Yun, J. W. Enzyme Microb. Technol. 1996, 19, 107-117.

4. Ziemer, C. J.; Gibson, G. R. Int. Dairy J. 1998, 8, 473-479.

5. Sangeetha, P. T.; Ramesh, M. N.; Prapulla, S. G. J. Food Eng. 2005, 68, 57-64.

6. Balasubramaniem, A. K.; Nagarajan, K. V.; Paramasamy, G. Process Biochem. 2001, 36, 1241-1247.

7. Chien, C.-S.; Lee, W.-C.; Lin, T.-J. Enzyme Microb. Technol. 2001, 29, 252-257.

8. Ghazi, I.; Gómez de Segura, A.; Fernández-Arrojo, L.; Alcalde, M.; Yates, M.; Rojas-Cervantes, M. L.; Plou, F. J.; Ballesteros, A. J. Mol. Catal. B: Enzym. 2005, 35 , 19-27.

9. Nishizawa, K.; Nakajima, M.; Nabetani, H. Food Sci. Technol. Res. 2001, 7, 39-44.

10. Duan, K. J.; Chen, J. S.; Sheu, D. C. Enzyme Microb. Technol. 1994, 16, 334-339.

11. Cohen, Y. Bioresour. Technol. 2001, 77, 257-274.

12. Cruz, R.; Cruz, V. D.; Belini, M. Z.; Belote, J. G.; Vieira, C. R. Bioresour. Technol. 1998, 65, 139-143.

13. Sankpal, N. V.; Joshi, A. P.; Sutar, I. I.; Kulkarni, B. D. Process Biochem. 1999, 35, 317-325.

14. Fenice, M.; Giambattista, R. D.; Raetz, E.; Leuba, J.-L.; Federici, F. J. Biotechnol. 1998, 62, 119-131.

15. Ramakrishna, S. V.; Prakasham, R. S. Curr. Sci. 1999, 77, 87-100.

16. Santos, J. C.; Mussatto, S. I.; Dragone, G.; Converti, A.; Silva, S. S. Biochem. Eng. J. 2005, 23, 1-9.

17. Skowronek, M.; Fiedurek, J. Enzyme Microb. Technol. 2006, 38, 162-167.

18. Shin, M.; Nguyen, T.; Ramsay, J. Appl. Microbiol. Biotechnol. 2002, 60, 218 223.

19. Anderson, R. A.; Conway, H. F.; Pfeifer, V. F.; Griffin, E. Cereal Sci. Today 1969, 14, 11-12.

20. Official Methods of Analysis of the Association of Official Agriculture Chemistry; Horwitz, W., Ed.; AOAC-Association of Official Analytical Chemists: Washington, DC, 1980.

21. Yoshikawa, J.; Amachi, S.; Shinoyama, H.; Fujii, T. FEMS Microbiol. Lett. 2006 265, 159-163.

22. Gómez, M. H.; Aguilera, J. M. J. Food Sci. 1983, 48, 378-382.

23. Limbut, W.; Thavarungkul, P.; Kanatharana, P.; Asawatreratanakul, P.; Limsakul, C.; Wongkittisuksa, B. Biosens. Bioelectron. 2004, 19, 813-821.

24. Senthuran, A.; Senthuran, V.; Hatti-Kaul, R.; Mattiasson, B. J. Biotechnol. 1999 $73,61-70$.

25. Yang, X.; Wang, B.; Cui, F.; Tan, T. Process Biochem. 2005, 40, 2095-2103.

26. Rodríguez Couto, S.; Sanromán, M. A.; Hofer, D.; Gübitz, G. M. Bioresour. Technol. 2004, 95, 67-72.

27. Spiegel, J. Food Technol. 1994, 48, 85-89.

28. Sánchez, O.; Gino, F.; Garcia, D.; Silva, E.; Caicedo, L. Food Bioprod. Process. 2008 $86,109-115$.

29. Pereira, M. A.; Alves, M. M.; Azeredo, J.; Mota, M.; Oliveira, R. J. Ind. Microbiol. Biotechnol. 2000, 24, 181-186.

30. Chen, W.-C. Process Biochem. 1998, 33, 267-271.

31. ul-Haq, I.; Ali, S.; Aslam, A.; Qadeer, M. A. Bioresour. Technol. 2008, 99, 7-12.

32. Wang, L.-M.; Zhou, H.-M. J. Food Biochem. 2006, 30, 641-658.

33. Nguyen, Q. D.; Mattes, F.; Hoschke, A.; Rezessy-Szabo, J.; Bhat, M. K. Biotechnol. Lett. 1999, 21, 183-186.

34. Kim, B. W.; Kwon, H. J.; Park, H. Y.; Nam, S. W.; Yun, J. W. Bioprocess Eng. 2000, 23, 11-16.

35. Dorta, C.; Cruz, R.; Oliva-Neto, P.; Moura, D. J. C. J. Ind. Microbiol. Biotechnol. 2006, 33, 1003-1009.

36. Fernández, R. C.; Maresma, B. G.; Juárez, A.; Martínez, J. J. Chem. Technol. Biotechnol. 2004, 79, 268-272.

37. Chen, W.-C.; Liu, C.-H. Enzyme Microb. Technol. 1996, 18, 153-160.

38. Mussatto, S.I.; Rodrigues, L.R.; Teixeira, J.A., to be published. 